\section{An Efficient Method for PCR Analysis of Mitochondrial DNA from Paraffin- embedded Archival Heart Tissue}

\section{Antonella Bobba, Rosa Lippolis, Sergio Giannattasio, Clara Camaschella, and Ersilia Marra}

Centro di Studio sui Mitocondri e Metabolismo Energetico, C.N.R. Bari, and ${ }^{1}$ Dipartimento di Scienze

Biomediche e Oncologie Umana, Universitá di Torino, and Centro di Studio per l'Immunogenetica e

Istocompatibilitá-Centro di

Immunogenetica e Oncologia Sperimentale, C.N.R., Torino, Italy
A growing amount of literature has pointed out the feasibility of using PCR to amplify small DNA fragments from paraffin sections of archival materials. $^{(1,2)}$ The availability of such samples could be of particular interest especially in the field of mitochondrial pathology because blood tests may not be diagnostic in all cases. Because of the heteroplasmic nature of mitochondrial DNA (mtDNA) mutations, frequent cell divisions in the leucocyte precursor could select against the survival of cells containing genetically defective mitochondria. ${ }^{(3)}$ Moreover, there is little in the literature on mtDNA amplification from paraffinated samples. Love et al. ${ }^{(4)}$ reported the amplification of a 216-bp fragment from mtDNA and pointed out the existence of limits to the size of fragments that can be amplified from such materials. For the above reasons, we have developed a rapid and simple protocol to amplify mtDNA fragments as long as $1000 \mathrm{bp}$ from paraffin-embedded heart tissue. Two 5- $\mu \mathrm{m}$ sections, containing $\sim 4 \times 10^{6}$ cells were cut from formalin-fixed, paraffin-embedded intraven- tricular septum of five subjects, one elderly and four young. Deparaffinization was achieved by adding $400 \mu \mathrm{l}$ of xylene to each sample. After $15 \mathrm{~min}$ of incubation of $37^{\circ} \mathrm{C}$ the sample was centrifuged at $13,000 \mathrm{~g}$ for $5 \mathrm{~min}$. The xylene was removed, and the pellet, after washing with $400 \mu \mathrm{l}$ of absolute ethanol, was incubated for $5 \mathrm{~min}$ at room temperature. After centrifugation, the ethanol was removed and the pellet lyophilyzed in Eppendorf tubes capped with sterile aluminum foil to prevent contamination. The pellet was resuspended in 200 $\mu \mathrm{l}$ of $10 \mathrm{~mm}$ Tris-HCl, $50 \mathrm{~mm} \mathrm{KCl}$, and 2 $\mathrm{mM} \mathrm{MgCl}_{2}$ (pH 8.3), containing 1.5 units of Pre-Taq (Life Technologies). ${ }^{(5)}$ To ensure complete resuspension, the sample was homogenized with a disposable pellet pestle mixer. The sample was incubated for $5 \mathrm{~min}$ at $75^{\circ} \mathrm{C}$, with the proteolytic reaction blocked by the addition of 2 mM EGTA and incubation prolonged for a further $5 \mathrm{~min}$ at $75^{\circ} \mathrm{C}$, following the manufacturer's instructions. Pre-Taqtreated samples were both used immediately for PCR amplifications and stored at $-20^{\circ} \mathrm{C}$ for up to 1 month. To check

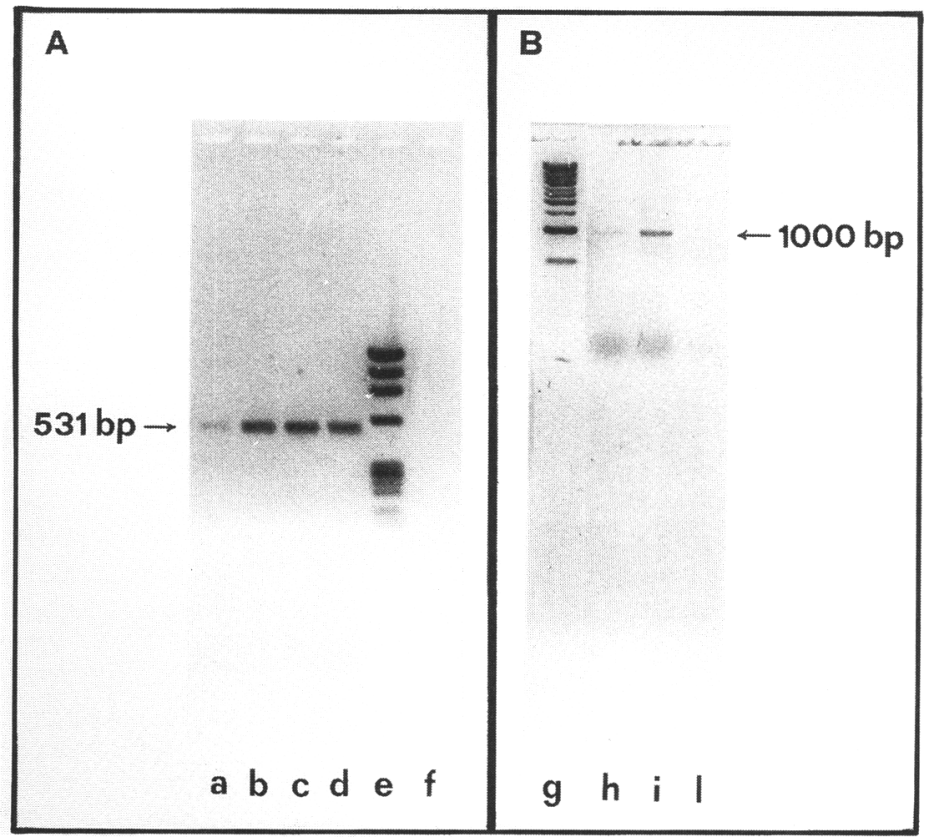

FIGURE 1 Agarose gel electrophoresis analysis. (A) Amplification product (531 bp) obtained with increasing amounts of template from Pre-Taq-treated elderly subject sample (lane $a$ ) $0.2 \mu \mathrm{l}$; (lane b) $1.0 \mu \mathrm{l}$; (lane $c$ ) $5.0 \mu \mathrm{l}$; (lane $d$ ) $10.0 \mu \mathrm{l}$. Amplification was for 25 cycles on a Perkin-Elmer Cetus thermal cycler $\left(1 \mathrm{~min}\right.$ at $94^{\circ} \mathrm{C}, 1 \mathrm{~min}$ at $55^{\circ} \mathrm{C}, 1 \mathrm{~min}$ at $72^{\circ} \mathrm{C}$ with a final extension of $5 \mathrm{~min}$ at $72^{\circ} \mathrm{C}$ ). (B) Amplification product (1000 bp) obtained with the Pre-Taq-treated elderly subject sample (lane $h$ ) $1 \mu \mathrm{l}$; and (lane $i) 5 \mu \mathrm{l}$. Amplification was for 30 cycles on a Perkin-Elmer Cetus thermal cycler $\left(1 \mathrm{~min}\right.$ at $94^{\circ} \mathrm{C}, 1 \mathrm{~min}$ at $51^{\circ} \mathrm{C}, 5 \mathrm{~min}$ at $72^{\circ} \mathrm{C}$ with a final etension of $5 \mathrm{~min}$ at $72^{\circ} \mathrm{C}$ ). (Lane $e$ ) Size markers HaelII-digested $\phi X 174$ phage DNA; (lane $g$ ) Kilobase ladder (Pharmacia); (lanes $f, l$ ) negative amplification control contained all components except DNA. 
for the presence of mtDNA, a 531-bp fragment from the conserved region across the 16S rRNA and the ND1 genes was amplified using primers positioned at nucleotides 3007-3023 (5'-CCCGATGGTGCAGCCGC-3') and 3538-3520 (5' - CTAAGGTCGGGGCGGTGAT-3'). The PCR reaction was performed in a volume of $100 \mu$ l containing $10 \mathrm{~mm}$ Tris$\mathrm{HCl}$ (pH 8.8), $50 \mathrm{~mm} \mathrm{KCl}, 1.5 \mathrm{~mm} \mathrm{MgCl}_{2}$, $0.1 \%$ Triton X-100, $200 \mu \mathrm{M}$ dNTPs, 50 pmoles of each primer, and 2.5 units of Dynazyme DNA Polymerase (Finnzymes Oy). The expected fragment was amplified from all five samples. The amplification product obtained by analyzing the elderly subject sample is shown as an example (Fig. 1A, lanes a-d). By using this method, we have been able to amplify a 1000-bp fragment from the elderly subject sample, making use of the following primers: 5-'ACGAAAATCTGTTCGCTTCA-3' positioned at nucleotides 8531-8550 and 5'-AAATTTGAAATCTGGTTAGG-3' positioned at nucleotides 400-381. The 1000-bp amplification product (Fig. 1B,lanes $h, i$ ) is proof of the presence of mtDNA molecules bearing the 7436-bp deletion that is found either in elderly subjects ${ }^{(6)}$ or in cardiomyopathic patients. ${ }^{(7)}$ The identity of the deletion was assessed by direct DNA sequencing. In the samples from the four young subjects, no 1000-bp fragment was detected. A primer shift PCR experiment was performed according to Hattori $^{(6)}$ using a third primer positioned at nucleotides $16540-16514$ (5'-GTGGGCTATTTAGGCTTTATGACCCTG-3') so that the shift in the position of the primers should parallel the shift in the size of the amplified fragment. No amplification product was detected, thus excluding the possibility that failure to amplify the fragment in the young subjects is attributable to insufficient template DNA.

Thus, it has been possible to amplify a 1000-bp fragment from human mtDNA of paraffinated tissue using a very quick and reliable procedure requiring minimal manipulation of the sample. The possibility of detecting mtDNA molecules harboring large deletions in such samples will certainly improve molecular studies on archival materials at the mitochondrial level.

\section{ACKNOWLEDGMENTS}

This work was partially financed by a grant from C.N.R. Target Project FATMA, and Telethon, Rome no. 429.

\section{REFERENCES}

1. Impraim, C.C., R.K. Saiki, H.A. Erlich, and R.L. Teplitz. 1987. Analysis of DNA extracted from formalin-fixed, paraffin-embedded tissues by enzymatic amplification and hybridization with sequencespecific oligonucleotides. Biochem. Biophys. Res. Commun. 142: 710-716.

2. Nordvag, B.Y., I. Ranlov, H.M. Frostad Riise, G. Husby, and M.R. El-Gewely. 1993. Retrospective molecular detection of transhyretin Met 111 mutation in a Danish kindred with familiar amyloid cardiomyopathy, using DNA from formalinfixed and paraffin-embedded tissues. Hum. Genet. 92: 265-268.

3. Holt, I.J., A.E. Harding, and J.A. MorganHughes. 1988. Deletions of muscle mitochondrial DNA in patients with mitochondrial myopathies. Nature 331: 717719.

4. Love, S., J.A.R. Nicoll, and E. Kinrade. 1993. Sequencing and quantitative assessment of mutant and wild-type mitochondrial DNA in paraffin sections from cases of MELAS. J. Pathol. 170: 9-14.

5. Moul, J.W., J.T. Bishoff, S.M. Theune, and E.H. Chang. 1993. Absent ras gene mutations in human adrenal cortical neoplasms and pheochromocytomas. J. Urol. 149: 1389-1394.

6. Hattori, K., M. Tanaka, S. Sugiyama, T. Obayashi, T. Ito, T. Satake, Y. Hanaki, J. Asai, M. Nagano, and T. Ozawa. 1991. Age-dependent increase in deleted mitochondrial DNA in the human heart: Possible contributory factor to presbycardia. Am. Heart J. 121: 1735-1742.

7. Ozawa, T., M. Tanaka, S. Sugiyama, K. Hattori, T. Ito, K. Ohno, A. Takahashi, W. Sato, G. Takada, B. Mayumi, K. Yamamoto, K. Adachi, Y. Koga, and H. Toshima. 1990. Multiple mitochondrial DNA deletions exist in cardiomyocytes of patients with hypertrophic or dilated cardiomyopathy. Biochem. Biophys. Res. Commun. 170: 830-836.

Received October 31, 1994; accepted in revised form January 24, 1995. 


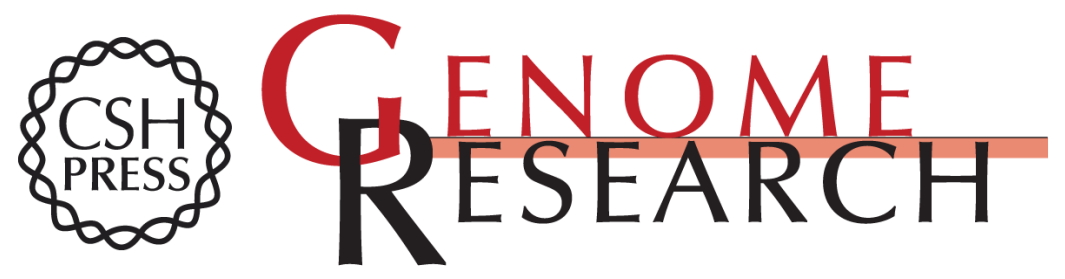

\section{An efficient method for PCR analysis of mitochondrial DNA from paraffin-embedded archival heart tissue.}

A Bobba, R Lippolis, S Giannattasio, et al.

Genome Res. 1995 4: 309-310

\section{License}

Email Alerting

Receive free email alerts when new articles cite this article - sign up in the box at the Service top right corner of the article or click here.

\section{Affordable, Accurate Sequencing.}

